\title{
A Picturesque Photographic Tour Through Scotland
}

\section{Elizabeth Knazook}

Ryerson University

\section{digital.library.ryerson.ca/object/80}

Please Cite:

Knazook, E. (2009). A picturesque photographic tour through Scotland. Genre: An International Journal of Literature and the Arts: Arrivals and Departures, 29, 127-159.

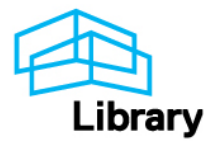




\title{
A Picturesque Photographic Tour Through Scotland
}

\author{
Elizabeth Knazook \\ Ryerson University, Toronto, ON/ George \\ Eastman House Museum, Rochester, NY
}

T $\mathrm{n}$ the autumn of 1844, William Henry Fox Talbot traveled to Scotland to photograph abbey ruins, 1 Gothic-style monuments, rivers, and rolling landscapes, using his newly patented calotype photographic process. The following summer, he printed twenty-three of the images in a book entitled Sun Pictures in Scotland, produced with salted paper prints from the calotype negatives. A gentleman scientist with a Cambridge education, Talbot was well-versed in the "picturesque" aesthetic that frequently informed landscape imagery, and the photographs in Sun Pictures demonstrate his understanding of picturesque composition. He directed the book on subscription to a wealthy, upper class audience, confident that it reflected an artistic sensibility shared by 


\section{Knazook}

himself and his readers. Yet, while Sun Pictures was generally well-received, little evidence exists to indicate the critical reception this small selction of picturesque scenes received from its contemporary audience. Furthermore, by omitting any narrative text from the book, Talbot himself left few indications of what he hoped would be understood from his work.

Uncovering Talbot's purpose with Sun Pictures in Scotland requires an examination of the contemporary print culture into which the book was placed, and an understanding of the nature of travel in the nineteenth century. While the subject matter of Talbot's views is unremarkable in an age flooded with travel publications, viewbooks, and memoirs, it is surprising that his photographic process did not revitalize the industry as it was likely poised to do. Sun Pictures in Scotland was the realization of the photograph's ability to compete with the arts of lithography and engraving, not merely in the reproduction of images, but also in the making of them. In this article, I will argue that the book borrowed from the existing canon of travel publications to create meaning and to fulfill the viewer's expectations of print images. In considering the book in terms of the market into which it was placed, I will focus not on the aesthetics of the pictures (which have been more than adequately discussed by Graham Smith, Larry J. Schaaf, and Martin Kemp), but the ways in which Talbot's first audience would have interpreted the visual information presented to them.

\section{Travel Publishing History}

In the early nineteenth century, the traveler's handbook or guidebook began to emerge with a distinct and predictable style, containing at the start a brief historical 


\section{Tour Through Scotland}

explanation of the area to be visited, followed by maps, sometimes pictures, and finally a gazetteer which, as the century wore on, increasingly favoured the railway as the primary means of travel. The guidebook genre aimed at offering advice, reassurance, and most importantly, directions to key sites of interest for an audience that included a more mobile middle class. The books presented the tourist with a means of traveling comfortably, which implied not merely physical comfort but the emotional safety of encountering a welcome reception at sites proximate to accommodations, servants, and services to be let (Mackenzie 24). Most travelers also turned to guidebooks for introductions to foreign ideas and cultural traditions, and they in turn became the primary resource for understanding previously dangerous or simply unexplored sites. By the 1830s, John Murray's publishing house would churn out guidebooks as its primary market item, the most popular of which were editioned almost annually $(22,35)$. Through print, the experience of travel became available to everyone.

While the market for tourism was growing increasingly homogeneous, the types of guides available to tourists diversified to accommodate the still-present social gap between upper and middle class travelers. Jill Steward has argued that "tourism in the second half of the nineteenth century began to serve as a vehicle for the expression of distinctive personal and social identities" (39), and that print became a resource prescribing and differentiating the social behaviors of various classes of travelers. A visual literacy underlined the textual one, and advances in printing techniques made pictures more widely available in the already exploding print market. The viewbook market grew alongside the production of guidebooks, aided by the predominance of the outdoor, locale-driven, 


\section{Knazook}

picturesque aesthetic in literary and artistic works. As a result, the public became as familiar with views of Loch Katrine as they did with the 1810 poem "The Lady of the Lake" that had originally popularized it. This variety of reference literature freed the personal travelogue to "specialize in recording an individual traveler's distinctive reactions to stimuli of the tour" (Buzard 49). So it was that by the mid-nineteenth century not only could anyone use the print media to facilitate travel, but they could also participate in the vanity of the travel author.

The development of photographic technologies in the 1840s helped to expand an author's publishing options, although for the larger part of the decade the term "photography" would have been associated with the commercially-successful daguerreotype, a process which produced a direct positive on a fragile metal plate. $\mathrm{Ni}$ colas-Marie-Paymal Lerebours, an entrepreneur, photographer, and publisher, found a solution to the inability to reproduce daguerreotypes by issuing a collection of engravings based on daguerreotypes, entitled Excursions Daguerriennes: Vues et monuments les plus remarquables $d u$ globe (1840-44). Lerebours sent photographers out to exotic locales such as Egypt and the Holy Land to daguerreotype scenes appropriate for the tourist market. The result was a serialized work that, when completed sometime on or after 30 October 1843, held between 111 and 114 aquatints in two or three volumes, depending on whether the owner had an earlier or later compilation (Email to author, David Harris, Professor Ryerson University, 17 June 2007). The Excursions were incredibly popular, and other would-be photographic publishers set out with daguerreotype equipment in hand (Buerger 27). The market for photographically inspired viewbooks grew quickly but, because of each daguerreotype's uniqueness, it was an in- 


\section{Tour Through Scotland}

dustry still largely based on the skill of the copy engravers. The volumes did not vary greatly from those already available on the print market, touching on subjects that, while exotic, were also anticipated and acceptable choices.

When Fox Talbot published a collection of views in 1845 of his trip to Scotland, the seemingly innocuous act of assembling a few images into a volume was actually situated to make some major alterations to the established travel publishing industry. Talbot's pictures were true photographs, reproduced through a positivenegative process that allowed multiple printings of the same image. In composition and style, they rivaled the best engravings, not least due to their use of popular travel imagery. According to an undated, pre-publication subscription announcement for the work (Smith 89), the book focused on locations associated with the life and work of Sir Walter Scott, an author famous for his lush descriptions of landscape and largely responsible for the popularization of the aforementioned Loch Katrine as a tourist destination. Talbot's decision to use subject matter most often associated with high art further established Sun Pictures as an artistic product in and of itself. The most attractive aspect of the book, however, was that Talbot had provided a means for an individual author to reproduce images without the engraver as an intermediary. Talbot had set a precedent by which any author could publish his or her own images.

\section{Photographs Versus Engravings}

While Sun Pictures in Scotland gained respectable sales on subscription, with at least 120 copies requested, it apparently failed in its purpose of highlighting the uniqueness of the method of reproduction and there- 


\section{Knazook}

fore democratizing the publishing industry as indicated above. Talbot himself does not seem to have desired to impress this onto his audience. In fact, he inserted only a small piece of paper measuring no more than $19 \times 7 \mathrm{~cm}$ into the spine on the fly leaf of the book, explaining to the reader what he or she was about to see:
Notice to the Reader. The plates of the pres- ent work are impressed by the agency of Light alone, without any aid whatever from the artist's pencil. They are the Sun-Pictures themselves, and not, as some persons have imagined, engravings in imitation.

This notice was not included in the first few copies of the book either, only added after reprobation from Talbot's business-minded mother in a letter on 29 July 1845, in which she argued that the subscribers who formed a good part of her social circle did not understand that they had received actual photographs rather than engravings (Letter, Lady Elisabeth Fielding to Talbot). She lamented the need to refer her peers to the preface of Talbot's earlier photographic book effort, The Pencil of Nature (1843-6), a six-part volume that explained the history of the invention in a straightforward manner, and produced examples of its utility and attractiveness. Since only the first two fascicles of Pencil had been printed with paper photographs prior to Sun Pictures, and since Talbot had taken out a rather restrictive patent on his process in 1843 , it is easy to understand their confusion.

Later biographers have taken this issue of mistaken identification to imply that the book was a promotional failure, supported by the fact that neither his publications nor the calotype process were ultimately financial successes for Talbot. It is true that if Talbot intended to 
use this book solely to encourage the understanding of his process, he did not succeed. He did not provide an explanation until several subscribers had already received their books, and when he did, it was a minor note. The book itself contained no text except for a title page and table of contents. So should we presume that Talbot, who had earlier made such a whole-hearted effort to explain the calotype's uses to a wide audience with Pencil, made a grave marketing mistake with Sun Pictures?

Talbot's apparent lack of interest in correcting the misperception that his photographs were engravings suggests either that he was indifferent, or that he sincerely desired the acceptance of photographs as direct replacements of drawings, even in apparent terms. He had earlier used Pencil to demonstrate the calotype's capabilities, expound the benefits, and suggest marketable uses and future improvements (in fact, due to Pencils serialized nature, he was still producing fascicles concurrent with Sun Pictures). In the preface to Pencil, Talbot recalled that his poor attempts at drawing the shore of Lake Como in 1831 drove him to the invention of photography, an invention that would entirely replace the need to sketch scenes in order to retain them on paper. Having made that claim in 1843 , he merely needed to prove that the camera could serve the eager tourist.

Academic scholarship has long concerned itself with the psychological and sociological implications of mass camera ownership, but when it comes to the early history-when the camera was still largely unavailable to the public - the meaning and function of expression with the camera is often treated on a case-by-case basis. Yet there was a homogenous cultural aesthetic available to the public in which the camera could and did participate, and it may be that Talbot thought his photographs constituted 


\section{Knazook}

the beautiful sketches he was unable to achieve by conventional drawing. Talbot is known to have favoured the picturesque aesthetic (Kemp 273), which Ann Bermingham has indicated was not merely a preferred style of art but a language with which to demonstrate one's social position (85). Perhaps Talbot's adoption of the accepted vocabulary of representation is the key to understanding his purpose. Put simply, the suggestion that Sun Pictures did not succeed as something new ignores the possibility that it was intended to pass for something traditional.

\section{The Introduction to the Book}

The prospectus for Sun Pictures in Scotland was printed at the end of May 1845 and the book itself was distributed to subscribers shortly after. The twenty-three photographs were bound with an elaborate green cloth cover and 120 copies were published (Arnold 157). Each copy, measuring $31.9 \times 24.3 \times 1.6 \mathrm{~cm}$ (measurements taken from the copy at the Canadian Centre for Architecture, Montréal) sold for 21s (or one guinea). Only three printed pages preceded the photographs themselves: the title page and the two-page List of Plates. The title on the cover was printed in a sans serif font, embossed in gold, and placed just above centre on the cover, framed by four decorative gold curls. This was followed by a title page announcing:

Sun Pictures in Scotland

By H. Fox Talbot, Esq., F.R.S.

\&c. \&c. \&c.

Juvat ire jugis qua nulla priorum castaliam molli devertitur orbita clivo.

London.

1845 . 


\section{Tour Through Scotland}

The title appeared in black-letter, the author's name and the publishing information in a serif, and the Latin phrase in a sans-serif. The phrase is a line from Virgil's Georgics, which has been translated as "Joyous it is to cross mountain ridges where there are no wheel ruts of earlier comers, and follow the gentle slope to Castilia" (Newhall). The imagery of the quotation is appropriate both to Talbot the scientist, uncovering a hitherto undiscovered aspect of the natural world for which there were "no earlier comers," and Talbot as a gentleman, qualified by his knowledge of the picturesque to appreciate that very nature.

Talbot's choice of a quotation from classical literature would have made the title page all the more elegant in the mind of the educated reader, who would have been comfortable with classical allusions in the consideration of painted scenes (Ballantyne 143-4). In Talbot's case, the quotation significantly associated the book with the familiar pastime of travel. William Gilpin (1724-1804) described the appeal of natural scenery as "the expectation of new scenes continually opening, and arising to his [the traveler's] view. We suppose the country to have been unexplored [my emphasis]" (qtd. in Whale 176). Like Virgil, Gilpin thought the experience of discovery "joyous," and those who traveled to the picturesque locations he described in his many guidebooks did so with the hope of finding a place of unspoiled nature. It is important to note that Talbot previously employed this quotation for the title pages of each fascicle of The Pencil of Nature. Talbot's choice of the line at that time may have had more to do with "Talbot the scientist" explaining the possible applications of his new invention. He was certainly hurried when producing Sun Pictures, which may have encouraged him to use this quotation again, but he could not 


\section{Knazook}

have overlooked its nuanced meanings. Thus, the Virgilian line on the title page of Sun Pictures places innovation in the comfortable setting of the rural, classical past, and conjures visions of a pleasant journey.

A list of the photographs followed the title page:

\section{List of Plates}

1. Heriot's Hospital, Edinburgh.

2. Sir Walter Scott's Monument, Edinburgh; as it appeared when nearly finished, in October 1844.

3. Abbotsford.

4. Entrance Gate, Abbotsford.

5. Hall Door, Abbotsford.

6. Effigy of Sir W. Scott's favourite dog Maida, by the side of the hall door at Abbotsford. It has a Latin inscription, nearly as follows: Maida marmoreâ dormis sub imagine Maida Ante fores domini sit tibi terra levis.

$\left.\begin{array}{l}\text { 7. } \\ \text { 9. }\end{array}\right\}$

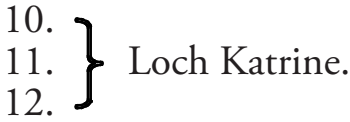

13. The Tomb of Sir W. Scott, in Dryburgh Abbey.

On the reverse side of the page:

$$
\begin{aligned}
& \text { List of Plates } \\
& \text { Smaller Views }
\end{aligned}
$$

14.Highland Hut on the banks of Loch Katrine.

$\left.\begin{array}{l}\text { 15. } \\ \text { 16. }\end{array}\right\}$ Scenery of Loch Katrine. 
18. The Castle Doune.

19. The same seen from the other side.

20. A Mountain Rivulet which flows at the foot of Doune Castle.

$\left.\begin{array}{l}\text { 21. } \\ \text { 23. }\end{array}\right\}$ Melrose Abbey.

The book contains no text beyond this point. Each salted paper print is framed by a single hand-inked line and identified by a handwritten number inside the lower right corner of the line border that corresponds to its number in the List of Plates. The sparse contents give hardly any further insight into the book.

\section{Re-Creating a Scottish Tour}

Fortunately, Talbot's correspondence for the period prior to and encompassing his trip to Scotland and the printing of Sun Pictures is widely available. If his book reveals little about his intentions, his letters more than adequately fill in the void:

I must now really transport my apparatus to some locality where picturesque objects are to be met with, such as a Cathedral, or a seaport Town, for my own neighbourhood is not particularly suited to the Artist. (Talbot, Letter to John Herschel, March 1841)

From these letters it is clear that Talbot desired to travel for artistic purposes and that he journeyed as a typical tourist: lodging in hotels, hiring guides for the more remote locations, and in all likelihood, carrying a guidebook. In Views of the North: Visions of Talbot, Turner and Scott, 


\section{Knazook}

Katherine Peveraro compared Talbot's account books with the sort of popular guidebooks to which he would have had access in order to establish Talbot as participant "in the same artistic tradition started by Turner, in photographing - as opposed to painting - the ruins etc. from the 'best view' angle" (32). The idea of the best view is adopted, naturally, from the notion that the painter's copy from nature might deviate from the real but still retain its resemblance to true nature. Edmund Burke, the influential eighteenth century author on the picturesque, beauty, and the sublime, argued fundamentally that pleasure was derived from our belief in a picture's similarity to the natural world (qtd. in Andrews, "The Picturesque-Literary Sources \& Documents" 124). Turner himself painted a scene for the frontispiece of one of Walter Scott's novels, depicting two travelers with sketchbooks observing an attractive waterfall observed-the most believable reality of all (Decker 171). In comparing Talbot to Turner, Peveraro established that Talbot's images could and should be viewed as an extension of the picturesque aesthetic applied to the photographic medium.

Peveraro is certainly not the first to have suggested Talbot was part of a larger aesthetic tradition, but what of the print culture surrounding the book itself? Most Scottish guidebooks offered a fairly flexible selection of excursions from which the tourist could arrange to see certain parts of the country, in any order, but these routes would typically begin at one of two major city centres: Edinburgh or Glasgow. Robert Chambers' The Picture of Scotland, published in 1840, offered a series of day-trips from Eastern and Western city bases so that the tourist literally saw the country as two halves. This urban-focused travel is echoed in the personal travelogues and viewbooks also published at the time. In Scotland Illustrated (n.d.), the 
author illustrates a train journey and so expects that the tourist has disembarked at Edinburgh first. In McLellan's Journal and Memoir (1834), Henry McLellan travels to Edinburgh from Northern England, and although he has the opportunity to catch a glimpse of scenic Abbotsford while on his way, he hastens by because he intended to return later. Perhaps most famously, Queen Victoria arrived by steamboat in Edinburgh's harbour for her visit to Scotland in 1843 . This formula stayed fairly consistent throughout the century, although it was occasionally ignored in personal travelogues at the peril of the author. As late as 1889, Joseph and Elizabeth Pennell received harsh criticism "for not giving second-hand descriptions, which are the stock and trade of Scotch guide-books, whether romantic or real; in a word, for not staying at home and manufacturing our journey in the British Museum" (Pennell, preface). It is very likely that, given Talbot's desire to take a picturesque tour, he followed a specific route from one of these publications and likelier still that the layout of his book is a version of that tour.

At a glance, it is easy to see how Talbot's images conform generally to the expected guidebook order of Urban Centre-Lowlands_Highlands. Larry J. Schaaf has suggested that Talbot traveled with Black's Picturesque Tourist of Scotland, which was fairly typical of this formula (Peveraro 6). The two opening views in Sun Pictures are distinctive landmarks of Edinburgh, showcasing the city as the starting point. Heriot's Hospital (Plate 1) offered Talbot the opportunity to show off his camera's adeptness at architectural scenes, while providing a literary connection to the next image in sequence, the Scott Monument (Plate 2). The Hospital was featured in Walter Scott's novel The Fortunes of Nigel (1831). Although the Scott Monument was still under construction when Talbot 


\section{Knazook}

photographed it, it was one of his most popular prints available for individual sale (Schaaf 202).

Suggested routes given early on in Robert Chambers' guidebook lead the tourist to Melrose and Abbotsford from Edinburgh, an area said to be full of so much of the charm of poetical and historical association, as to be immediately noticed by the tourist. Talbot did arrange scenes of Abbotsford and Melrose next in sequence, even though in reality he photographed these locations near the end of his trip due to "[e]xtremely dark weather" on his first pass through the area (Letter, Talbot to Constance Talbot, 9 October 1844). It was not unusual for travel memoirs to be edited, and it could be that Talbot thought the book's arrangement more attractive than his own tour, where he failed to obtain photographs on his first trip through the Borders.

An example of a logical edit would be the placement of Dryburgh Abbey at the end of the sequence of large views. While Dryburgh was one of the first stops on Talbot's tour, and was typically part of an Abbotsford-Melrose trip, Talbot has chosen to remove the abbey from the context of the tour and place it after the Highland photographs of Loch Katrine. The best explanation for Talbot's variance on this point may have to do with his desire to evoke the life of Walter Scott with his subjects. Abbotsford and Melrose were deeply associated with Scott's life, and Dryburgh his death, much the same way that Loch Katrine was with his oeuvre. Loch Katrine physically cannot be visited together with the house and abbeys because of its location farther north, but it does complement the other three sites well. This choice of embedding the Loch Katrine views within the Lowland grouping, when taken in context with whole of the large views, demonstrates that although Talbot allowed himself some flexibility 


\section{Tour Through Scotland}

within the location groups, he remained faithful to the idea of the city centre providing the point from which to "embark" upon the landscape. Since Talbot printed very few of his photographs - only twenty-three in totalplacing the site of Scott's burial at the end of the series of photographs that refer to his life makes logical sense, and is an understandable deviance from the norm.

\section{A Journey Within a Journey}

Given the similarity between the arrangement of the pictures and guidebook-approved routes, the book was likely constructed to give the viewer a much-needed sense of order. It may be possible to glean something more of Talbot's rationale for the order of the pictures, then, by considering how he treated locations where he had more than one representative photograph.

There are three groups of photographs in the larger views that show the environment of three different locations: Abbotsford, the ancestral home of Walter Scott; Melrose Abbey, a picturesque façade; and Loch Katrine. The way these images are ordered within the larger scope of the book is arguably representative of an individual tourist's experience of each place, a predilection even today in album-making and topical book publishing (Nordström 87). It seems likely that Talbot arranged the photographs in an order that echoed the way he approached the sites himself.

Talbot's three photographs of Abbotsford Hall (Plates 3, 4, and 5) are a case in point. Plate 3 is a view of the entire estate from a distance, a view that would have been captured from the South-East. This is followed by Plate 4, a view of Sir Walter Scott's Entrance Gate, and then Plate 5, a photograph taken of the main door to the 


\section{Knazook}

house. In this order, the photographs draw the viewer closer to the house in three successive stages. Talbot concludes the group of large Abbotsford views with the statue of Scott's dog Maida, which was visible at the side of the Hall door in the preceding photograph, Plate 5. Talbot went to the trouble of draping a black cloth behind the stone dog to block out the building behind, which implies that this was not meant to be part of the official Abbotsford group, but conforms to a logical movement in which one must be closer to the building to see the statue properly. The final photograph in the Abbotsfordrelated imagery is therefore the one that is closest to the building. All images courtesy of George Eastman House Museum, Rochester, NY.

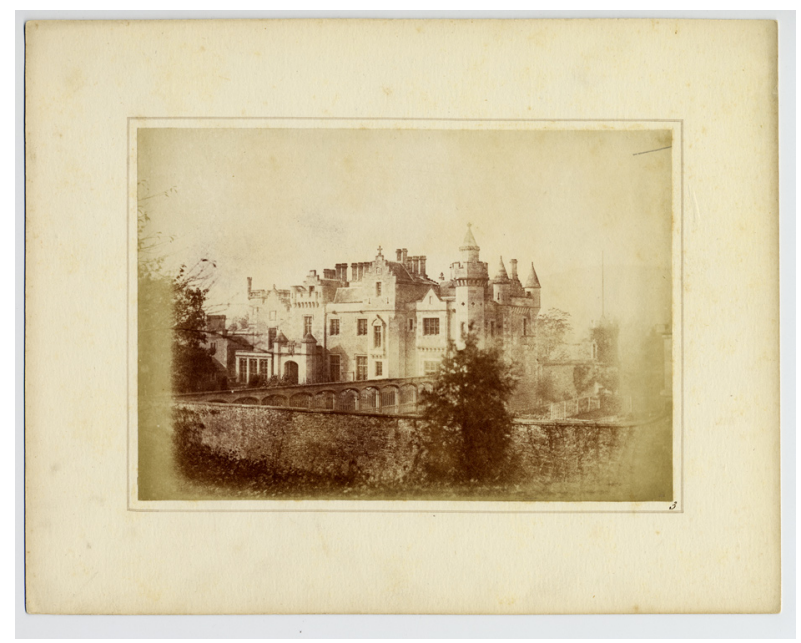

Plate 3, Abbotsford. ${ }^{1}$ 


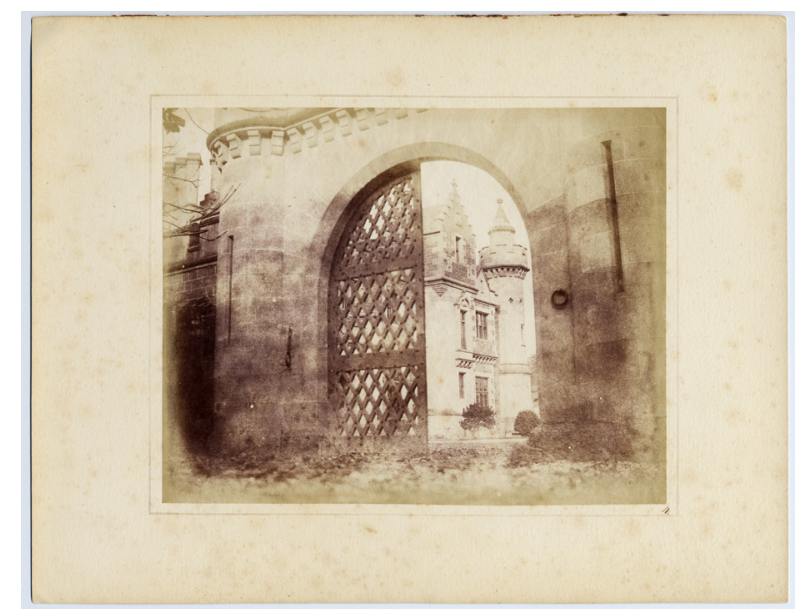

Plate 4, Entrance Gate, Abbotsford.

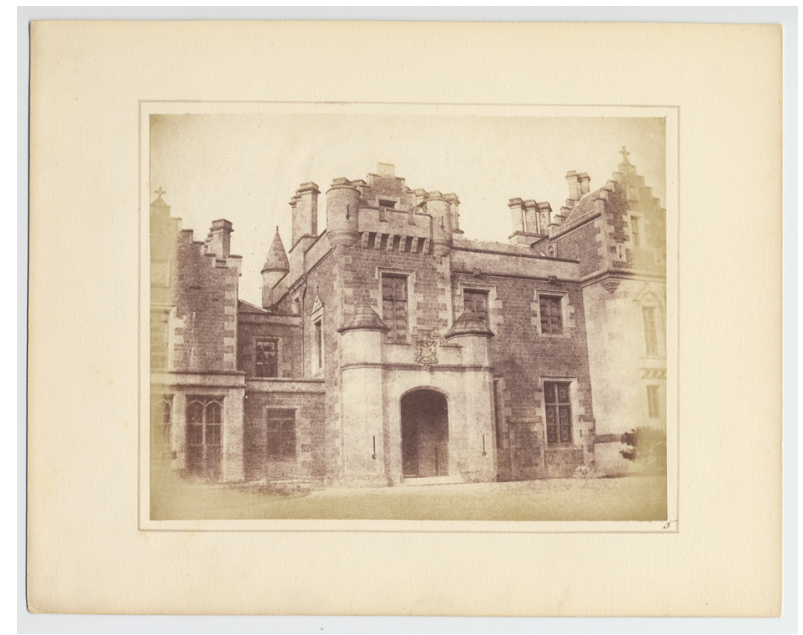

Plate 5, Hall Door, Abbotsford. 


\section{Knazook}

The realistic experience of approaching a building is reinforced if one also considers the large photographs of Melrose Abbey (Plates 7, 8, and 9). These views begin with a picture of the Gothic cathedral from the SouthEast, looking towards the southern transept crossing. In this first photograph, one sees the cemetery in the foreground as well as the southern entranceway, which is then brought into closer focus in Plate 8. The southern entrance was generally the lay entrance and more elaborately decorated than the northern or even western portals. In Plate 9, Talbot has moved down the southern side towards the West to photograph the missing roof over the long basilica portion of the building. At Melrose Abbey, movement along the Southern side from the Eastern end of the building to the Western end helps the viewer experience the whole cathedral.

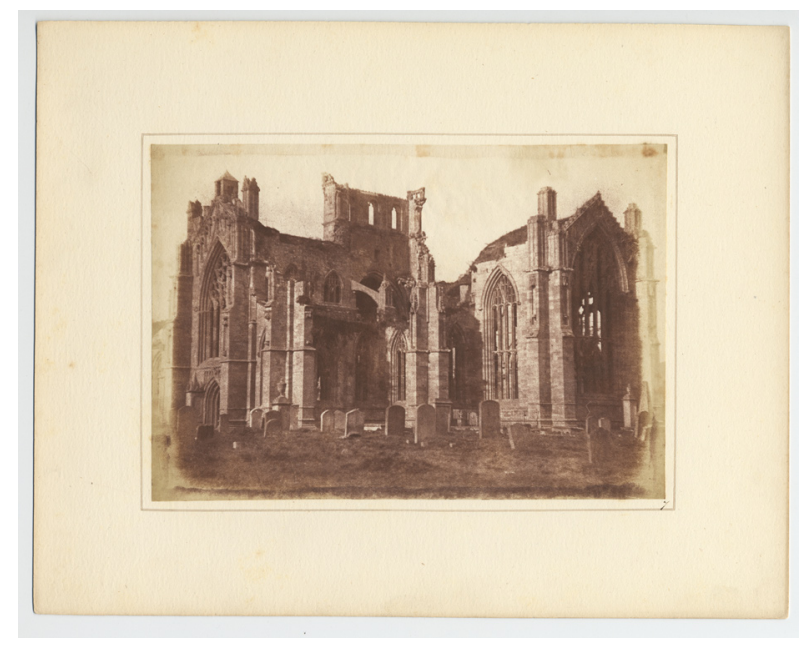

Plate 7. 


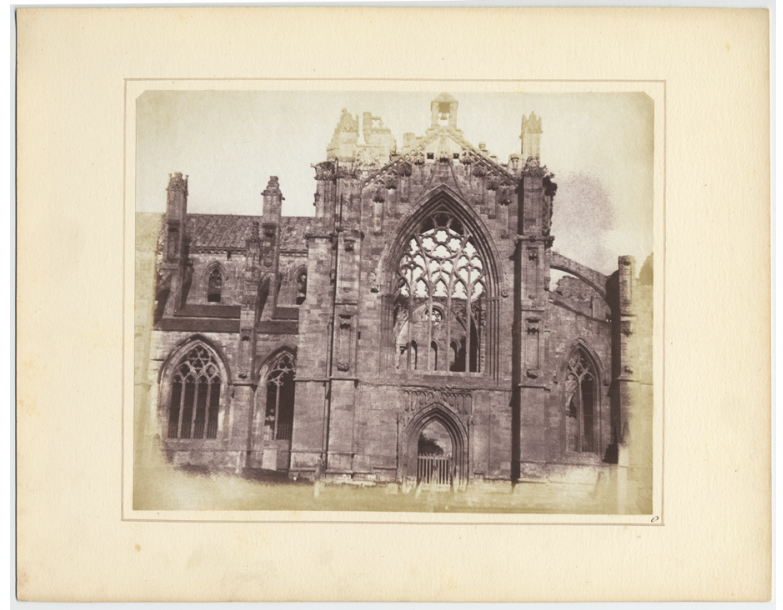

Plate 8.

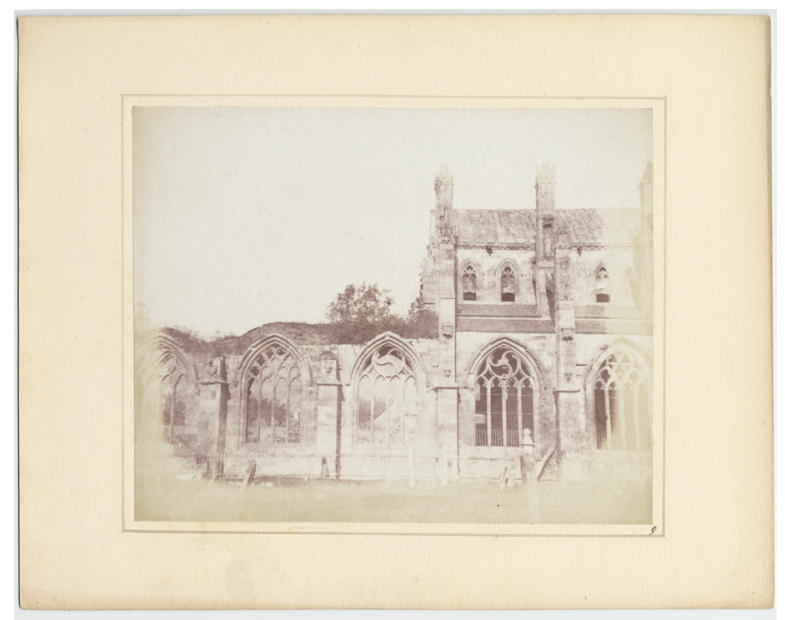

Plate 9. 


\section{Knazook}

The final set of large views depicts a visit to Loch Katrine (Plates 10, 11, and 12). Graham Smith has described the orientation of the first two images as taken from the East end of the loch, with the third (Plate 12) looking SouthWest at the mountain of Ben Venue ("Views of Scotland" 119). Although there is no clear starting or finishing-point to the Loch Katrine visit, as there is in the architectural views, Talbot seems to have again ordered his photographs to echo the real-life experience of visiting the loch. According to John Leighton in The Lakes of Scotland (1836), the approach from the East was the principal road by which to arrive at the loch, and since we know Talbot had come from Callendar, his choices were limited to either the eastern or southern roads. The Scottish Tourist describes the Eastern end of the lake as literally "bursting upon the view" from this direction, and Talbot's first photograph with the sharp, craggy eastern face of the mountain of Ben A'an appears to echo this sentiment. He took two photographs from this angle, Plates 10 and 11, though arguably the most picturesque scene is Plate 12, for which he traveled a little way along the North shore. Here he photographed the western side of Ben Venue, a gentler mountain slope, and allowed some of the northern bank to show on the right to create a very traditional, tripartite division of the picture plane favoured by picturesque compositions. A probable continuation of this route would have been to take the ferry to Ellen's Island, a location just outside of the frame on the left of Plate 12. Schaaf has observed that Talbot did not travel over to the island, named after the heroine of "The Lady of the Lake," supposing that Talbot preferred not to trust his photographic equipment to a small oar-boat ("The Photographic Art of William Henry Fox Talbot" 206). Although Talbot did not venture to the island, this set of photographs seems to indicate he was traveling there. 


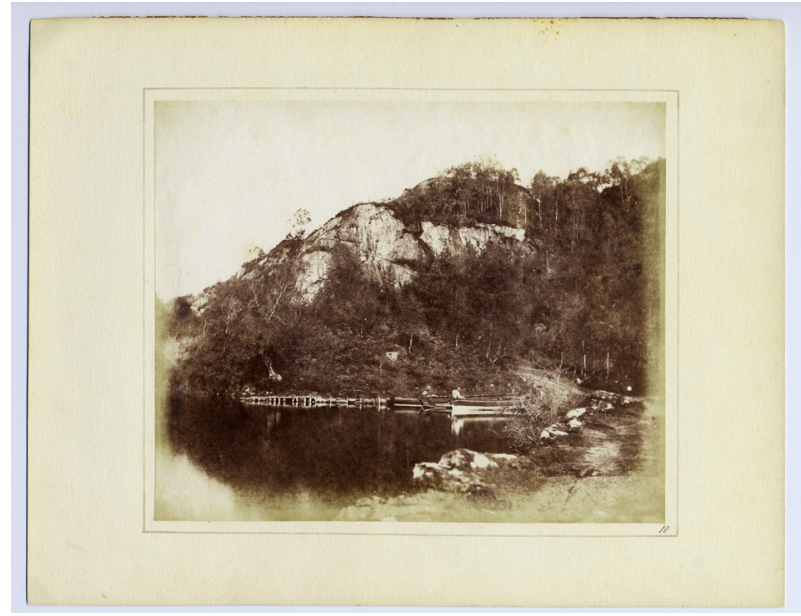

Plate 10.

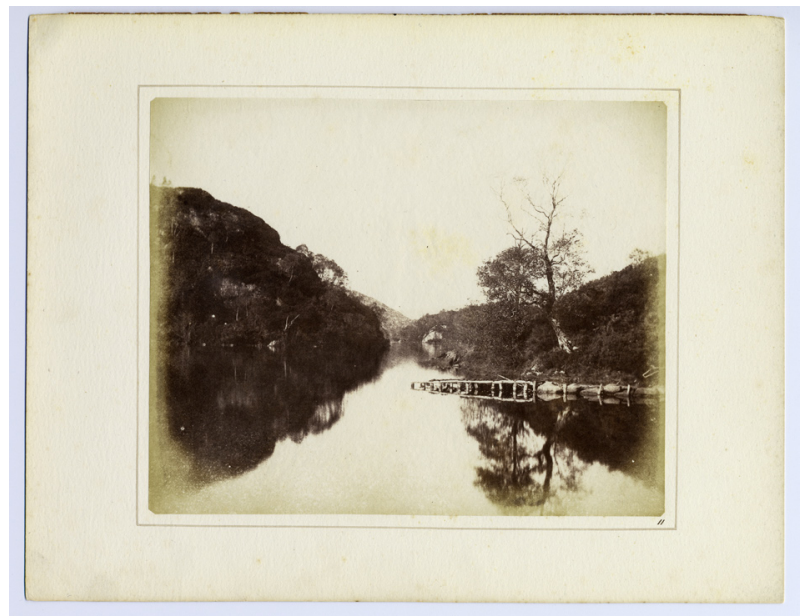

Plate 11. 


\section{Knazook}

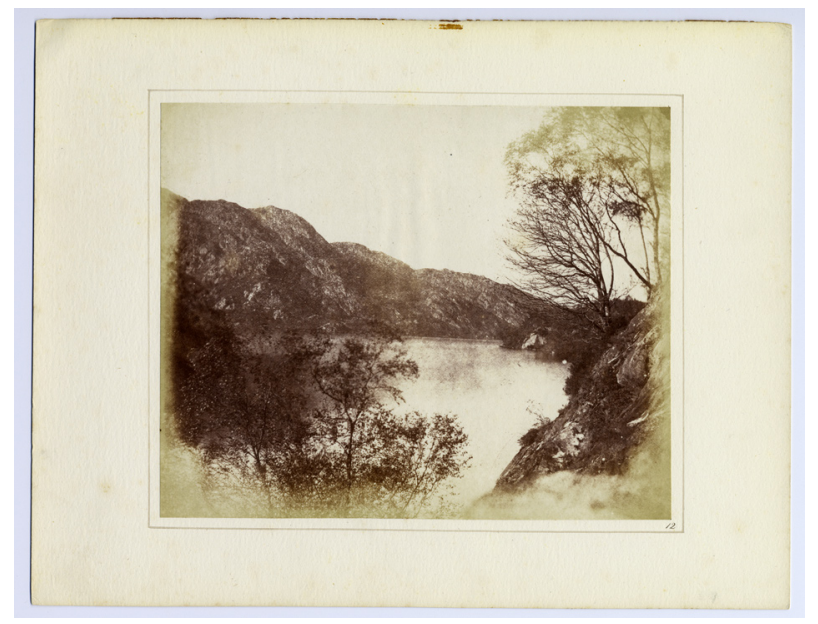

\section{Plate 12.}

\section{The Queen's Tour}

It is important to address the smaller set of photographs in Talbot's book as well, for although they duplicate some of the larger images, they are part of the book's overall presentation. At first glance, their existence seems due to practicality; Talbot photographed with two different cameras that produced differently-sized prints, and he chose the best images from both the large and small sets to publish in the book. Almost a decade after his Scottish tour, Talbot wrote to The Literary Gazette that he invented a "traveller's camera." This was specifically designed to photograph in rustic locations where the normal apparatus would be more difficult to transport, and was developed in part as a result of his constant frustrations with poor weather and failed photographs on his 1844 trip: 


\section{Tour Through Scotland}

It was in this way that in September, 1844, I made a series of views of Abbotsford, the residence of Sir Walter Scott, which were published by subscription in 1845 , in a small volume, entitled, Sun Pictures in Scotland. [...] But this method had, in the first place, the inconvenience of being exposed to occasional failure, which required all the principal points of view to be taken in duplicate as a necessary precaution. (876)

He clearly had several cameras in tow for the Scottish trip, even if the smaller camera used was not the same as his later "traveller's camera." At Lacock Abbey, he already had cameras that could photograph at approximately $160 \times 200 \mathrm{~mm}$ and $79 \times 109 \mathrm{~mm}$ (Email to author, Roger Watson, Curator, Fox Talbot Museum, 22 June 2007), and he wrote to Charles Fellows as early as August 1843 that "you will do well to take two Camera Obscuras with you, one of them small, of the size of mine, which works quickly." This desire to "back-up" his principle views could account for the fact that in at least four cases the smaller views he published in Sun Pictures are almost identical to pictures in the larger views.

Even if Talbot had different sizes to choose from for his photographs, it is probable that he placed the photographs from the smaller camera at the back of the book rather than intermingling them because there was some precedent for doing so. The wealthy nineteenth-century viewer, of the kind that purchased Sun Pictures on subscription, would doubtless have been familiar with a variety of travelogue types. It has already been observed that subjects were usually arranged sequentially to mimick a trip; however there is some room for thematic groupings within that arrangement, if only because the Highland 


\section{Knazook}

and Lowland portions of the country are usually encountered at different times in the journey.

I will now consider Talbot's choice of printing sizes in light of a highly influential travelogue, Queen Victoria in Scotland (1842-43), from which he may have borrowed some visual cues. The first half of the book is lavishly illustrated with high-quality lithographed drawings depicting Queen Victoria and Price Albert's visit to the Highlands shortly after their marriage. Scottish lithographers Maclure and Macdonald of Glasgow were employed to make the prints of this historic tour, which was then printed in Edinburgh by A \& C Black. The lithographs are tipped-in between pages of text in the book and decorated with the same single-ruled border that appears around Talbot's plates. This treatment only applies to the depiction of events in the Lowlands, however, and when the Queen's route ventures northward into the Highlands in the second half of her book, the style of illustration and printing changes noticeably. The nature scenes and depictions of Highlanders in traditional dress are smaller and are not contained by a border, although still printed one to a page.

This was only the second time that an English monarch had visited Scotland since the fifteenth century, and although the Queen's tour was first published by a Scottish firm, it had a distinctively English-minded market. The views in the book probably echoed something of Queen Victoria's sentiments at the time, which distinguished the urban population of Scotland as newly refined and gentle, with architecture to match any civilized society:

The view of Edinburg (sic) before you enter Leith is quite enchanting; ...Albert said he felt sure the Acropolis could not be finer; 
and I hear they sometimes call Edinburg (sic) the modern Athens. (27)

I propose that there is an attempt by the publisher of the memoirs, echoed in Talbot's book, to visually separate the scenes of more authentic "Scottishness" by presenting them as smaller and at the end of the book. The Scottish culture that Walter Scott embraced was indeed retreating into the Highlands as the Lowlands became more "civilized," dividing the country temporally as well as geographically-the Highlands representing the past, the Lowlands, the future.

Talbot may have decided that some versions of his Loch Katrine views, with their more rustic accoutrements

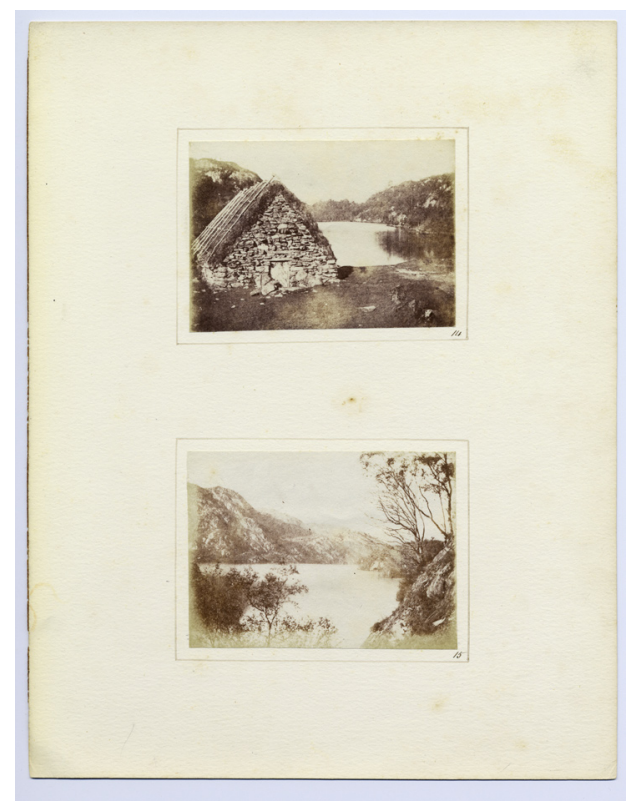

Plates 14-15. 


\section{Knazook}

in the form of "Highland Huts," were suited to a section at the back of the book that contained more traditionally Scottish subjects. The smaller group of Loch Katrine photographs (Plates 14-17), in comparison to the larger group mentioned above, is a relatively static arrangement. We see the image of the "Highland Hut" in Plate 14, followed by two views of the loch, and then another view of the hut with the blurred figure of a man standing in front of it. Talbot's wording in the title page suggests that he did not see all four photographs as a single group; Plate 14 is titled "Highland Hut on the banks of Loch Katrine" while the other three are grouped as "Scenery of Loch Katrine." These two images are further separated by a page break, the first appearing at the top of the first page of small views, and the other at the bottom of the next.

Doune Castle (Plates 18-20), with its river in Plate 20 quaintly termed a "rivulet" in Talbot's caption, was the perfect addition for a section of rustic views. Although Scott's description of the castle in his novel Waverley vividly imbues the "gloomy" bastion with the mystery of a Gothic romance, Talbot's scenes are not at all imposing. The mountain rivulet was a unique composition for Talbot; the camera has focused on the opposite bank of the stream at a low angle, making the attractive scattering of rocks in the shallow portion of the riverbed the focal point. With this composition, Talbot offers the viewer an intimate view.

The castle images are also unlike any of the larger architectural views. Talbot photographed the castle from two angles, one from the front and one from the back, and then a detailed view of a river on the property with part of the castle wall visible in the upper left. In the rear view of the castle, Talbot has traveled quite a distance into the landscape and turned around to look back at 


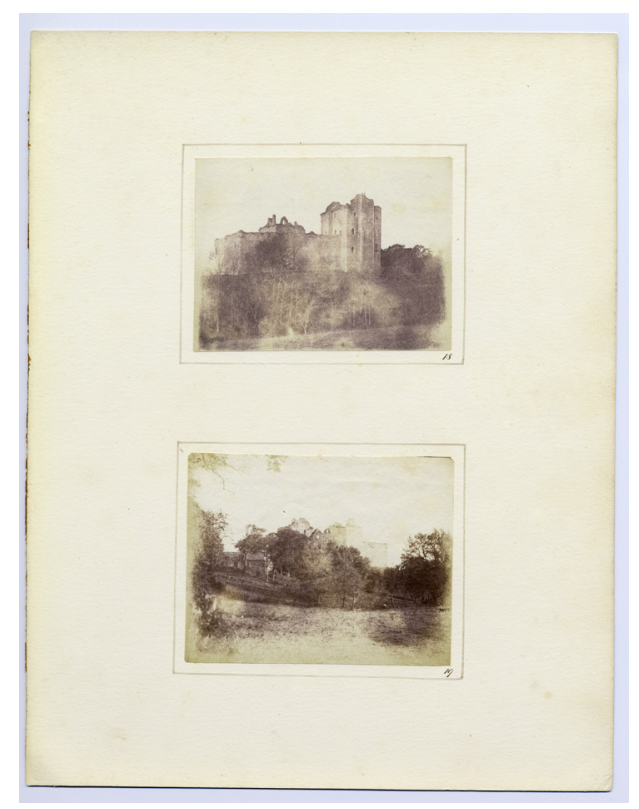

Plates 18-19.

the castle. His interest is therefore to show the full view of the castle rather than a journey through the grounds, emphasized by the fact that in neither the front nor back view does one see where the river is located-the subject of the third view. The reading of each of the small locations as individual illustrative scenes further annexes the smaller views into a different thematic group.

The deliberate choice to put photographs representative of a rustic naturalism in the second half of the book, and in a smaller format, is further supported by the fact that Talbot did take larger photographs of Doune that were not included in the book. A document giving the prices for "Large Prints" from the Reading Establishment for 1846 lists "River Doune" as one of the sub- 


\section{Knazook}

jects. The same document lists "River Doune" again as a $1 / 4$ sheet size print for sale (Henneman). Talbot certainly took more photographs in Scotland on his trip than he published in Sun Pictures, but that there may have been no material need to print this subject smaller than the rest is revealing. Indeed, the small scenes expose Talbot's general reluctance to engage the Highland terrain. Talbot only photographed locations, which Chambers observes could be captured on "the shortest and briefest tour": Doune Castle (near Callendar), the Trossachs, and Loch Katrine (Chambers 384).

The choice to place a set of three Melrose Abbey scenes that almost duplicate the larger views at the end of the book lends them a different meaning in this case, and suggests that Talbot was more comfortable with pictorial scenery rather than the emerging "Gothic." Ruins were particularly favoured for the picturesque aesthetic, universally in garden design, painting, and sketching; their picturesqueness often proportional to the degree of ruination. In the Melrose photographs, one can see that the roof is missing and the North wall is completely open to light and invading plant life. Melrose Abbey is thus adaptable to both the larger views, where one can imagine the visit, and the smaller ones, where the photographs act more as embellishments than markers of a specific location.

Unfortunately it is not possible to determine whether Talbot owned Queen Victoria in Scotland. The current Lacock Abbey library records reveal no collections of views (Email to author, Roger Watson, Curator, Fox Talbot Museum, 9 August 2007). Yet Talbot had so many artistic personalities in his life, including his mother, sister Caroline, and Uncle William Fox-Strangeways, that he would undoubtedly have discussed view books or trav- 


\section{Tour Through Scotland}

elogues, even if he did not collect them. It is clear that Talbot's mother made sure that he at least knew about market prices for illustrated books, as seen in her letter of 8 January 1845 :

I see there is a new Edition of Lord B's Childe Harold, illustrated with sixty prints! for one guinea! ... I see too that Moore's Irish Melodies are advertised with 154 designs by the celebrated Maclise.

It is likely, then, that Talbot would have had access to this particular view book, one which was both recent and widely popular. Talbot may have even modeled his tour after the royal one, as is suggested by a letter he later received from friend Calvert Jones in 1845 asking whether "any points of decision regarding your [Talbot's] Belgian or Queen's tour" had been made. Although the specific tour Jones inquired about was to have taken place in 1845 in Germany (but never occurred), Talbot was clearly aware of the Queen's travels.

\section{Conclusion}

Given that just two years after printing Sun Pictures in Scotland Talbot would publish a meticulous treatment of the history of language entitled English Etymologies, it is plausible and necessary to assume that he thought carefully about the arrangement of the photographs in Sun Pictures. Indeed, Talbot's reliance on public acceptance of his calotype process for this purpose dictated that he should use a recognizable aesthetic and familiar layout to underline the book's equivalence to other publications, and the lack of textual context seems to further emphasize this expected awareness on the part of the viewer. 


\section{Knazook}

Throughout the book, and within the groups of photographs of individual locations, it is possible to see that Talbot was thinking about his book in terms of the larger market for travel publications.

Note

${ }^{1}$ All the plates in this paper are courtesy of George Eastman House Museum, Rochester, NY. 


\section{Works Cited}

The Picturesque: Literary Sources \& Documents, Volume I. Ed. Malcolm Andrews. East Sussex, UK: Helm Information Ltd. 1994.

Arnold, H.J.P. William Henry Fox Talbot; Pioneer of Photography and Man of Science. London: Hutchinson Benham, 1977.

Ballantyne, Andrew. Architecture, Landscape and Liberty: Richard Payne Knight and the Picturesque. Cambridge: Cambridge University Press, 1997.

Bermingham, Ann." 'An Exquisite Practice': The Institution of Drawing as a Polite Art in Britain." Towards a Modern Art World, Studies in British Art 1. Ed. Brian Allen. New Haven and London: Yale University Press, 1995.

Buerger, Janet E. French Daguerreotypes. Chicago: University of Chicago Press, 1989.

Buzard, James. "The Grand Tour and after (1660-1840)." The Cambridge Companion to Travel Writing. Eds. Peter Hulme and Tim Youngs. Cambridge: Cambridge University Press, 2002.

Chambers, Robert. The Picture of Scotland. 4th Edition. [n.p.]: Robert Chambers, 1840.

Decker, George. The Fictions of Romantic Tourism: Radcliffe, Scott and Mary Shelley. Stanford, California: Stanford University Press, 2005.

Green, Samuel G. and Thomas Faulkner. Scotland Illustrated. New York: Hurst, [n.d.].

Henneman, Nicolaas. "Stock of Pictures." Ledger, British Library. 1846. LA46-2.

Kemp, Martin. "Talbot and the Picturesque View - Henry, Caroline and Constance," History of Photography. 21.4 (1997): 270-282. 


\section{Knazook}

Leighton, John M. Esq. The Lakes of Scotland. Joseph Swan, Engraver. London: Hodgson, Boys and Graves. 1836.

Lerebours, N.P. Excursions Daguerriennes: vues et monuments les plus remarquables du globe. Paris: Rittner et Goupil, 1840-1842.

MacKenzie, John M. "Empires of Travel: British Guide Books and Cultural Imperialism in the 19th and 20th Centuries." Histories of Tourism: Representation, Identity and Conflict. Ed. John K. Walton. Clevedon, England: MPG Books, 2005.

McLellan, I. Jr. McLellan's Journal and Memoir. Boston: Allen and Ticknor, 1834.

Newhall, Beaumont. The Pencil of Nature. New York: DaCapo Press, 1969.

Nordstrom, Alison. Voyages [Per]formed: Photography and Tourism in the Gilded Age. Chicago: The Union Institute, 2001.

Pennell, Joseph and Elizabeth Robbins. Our Journey to the Hebrides. New York: Harper \& Brothers, 1889.

Peveraro, Katherine. Views of the North: Visions of Scotland From Talbot, Turner and Scott. M.Litt. thesis, University of St Andrews, 2004.

Queen Victoria in Scotland. Edinburgh: A \& C Black, 1842-1843.

Queen Victoria and Prince Albert. Leaves from the Journal of Our Life in the Highlands, from 1848-1861; to which are prefixed and added extracts from the same journal giving an account of Earlier Visits to Scotland, and Tours in England and Ireland, and Yachting Excursions. Ed. Arthur Helps. New York and Toronto: Harper \& Brothers, W.C. Chewett \& Co. 1868.

Schaaf, Larry J. The Photographic Art of William Henry 


\section{Tour Through Scotland}

Fox Talbot. Princeton and Oxford: Princeton University Press, 2000.

Smith, Graham. "William Henry Fox Talbot's Views of

Loch Katrine," Bulletin of University of Michigan's Museums of Art and Archaeology 7 (1984-1985): 49-77.

Steward, Jill. "'How and Where To Go': The Role of Travel Journalism in Britain and the Evolution of Foreign Tourism, 1840-1914." Ed. John K. Walton. Histories of Tourism: Representation, Identity and Conflict. Clevedon, England: MPG Books, 2005.

Talbot, William Henry Fox. Sun Pictures in Scotland. London: n.p. 1845.

---. The Pencil of Nature, Anniversary Facsimile. New York: Hans P. Krauss, Jr. Inc., 1989.

---. "The Traveller's Camera." The Literary Gazette and Journal of belles letters, science and art. 1871, 27 November 1852.

---. The Correspondence of William Henry Fox Talbot. Ed. Larry J. Schaaf. De Montfort University, Leicester and The University of Glasgow, Glasgow. <http:// foxtalbot.dmu.ac.uk/index.html>

The Scottish Tourist. Edinburgh: Stirling and Kenney, 1834.

Whale, John. "Romantics, Explorers and Picturesque Travelers." The Politics of the Picturesque. Ed. Stephen Copley and Peter Garside. Cambridge: Cambridge University Press, 1994. 175-195. 